\title{
Icariside II: Anticancer Potential and Molecular Targets in Solid Cancers
}

\author{
Fei $X u^{1,2}$, Qiaolan $W^{2}{ }^{2}$, Lei $\mathrm{Li}^{3}$, Jie Gong ${ }^{3}$, Ran Huo ${ }^{1}$ and Wenqiang Cui ${ }^{4 *}$ \\ ${ }^{1}$ Department of Geriatric Medicine, Affiliated Hospital of Shandong University of Traditional Chinese Medicine, Jinan, China, ${ }^{2}$ First \\ Clinical Medical College, Shandong University of Traditional Chinese Medicine, Jinan, China, ${ }^{3}$ Affiliated Hospital of Shandong \\ University of Traditional Chinese Medicine, Jinan, China, ${ }^{4}$ Department of Neurology, Affiliated Hospital of Shandong University of \\ Traditional Chinese Medicine, Jinan, China
}

Icariside II, an active flavonoid, is extracted from the traditional Chinese medicinal herb Epimedii. It possesses multiple biological and pharmacological properties, including antiinflammatory, anticancer, and anti-osteoporotic properties. In recent years, apoptosis has become the hot spot in anticancer therapies. Icariside II exerts positive effects on inducing apoptosis and inhibiting proliferation in various cancers. The antitumorigenic activity of Icariside II was also proven through cell cycle arrest, triggering autophagy, reducing cellular metabolism, and inhibiting cancer metastasis and tumor-associated angiogenesis. Additionally, Icariside II, as a natural product, contributed to a synergistic effect alongside chemotherapeutic drugs. Due to its poor aqueous solubility and permeability, more strategies were developed to improve its therapeutic effects. This review aimed to summarize the chemopreventive properties of Icariside II in solid tumors and reveal its underlying molecular mechanisms.

Keywords: Icariside II, tumor, chemopreventive property, Epimedii, anti-apoptosis

\section{INTRODUCTION}

Cancer is the second leading cause of death worldwide, after cardiovascular diseases, and it claimed the lives of 9.6 million individuals in 2018 (Ambekar and Kandasubramanian, 2019). The four most common cancers include lung cancer, colorectal cancer, breast cancer, and prostate cancer. In the past decades, the increasing understanding of cancer biology drove the rapid development of new anticancer therapeutics, including chemotherapy, radiotherapy, surgery, targeted therapy, and immunotherapy. However, despite the rapid expansion in drugs and therapeutic options, there are still few malignancies that respond well to these agents. Moreover, the prognosis of some cancer patients remains very poor, accompanied by recurrence or metastasis. It has, therefore, become necessary to seek novel treatment strategies.

At present, natural products have gradually become acceptable for preventing or treating cancer due to their safety and low toxicity. There are reports showing that almost $80 \%$ of anticancer drugs contain natural compounds or mimic their efficacy and construction (Bishayee and Sethi, 2016). Herba Epimedii (commonly named as Yin-yang-huo or Xin-ling-pi in China) is commonly used as a traditional herb or functional food to prevent diseases in China. It was first recorded in the Chinese medical classic Shennong Classic of Materia Medica (commonly named as Shen Nong Ben Cao Jing in China) 400 years ago. Icariin $\left(\mathrm{C}_{33} \mathrm{H}_{40} \mathrm{O}_{15}, 676.60 \mathrm{~g} / \mathrm{mol}\right.$, Figure 1) is one of the major substances found in Herba Epimedii, and Icariside II (also named baohuoside I, $\mathrm{C}_{27} \mathrm{H}_{30} \mathrm{O}_{10}, 514.57 \mathrm{~g} / \mathrm{mol}$, Figure 1) is the main pharmacological metabolite of icariin in vivo and can be obtained from icariin under enzymatic hydrolysis conditions. 


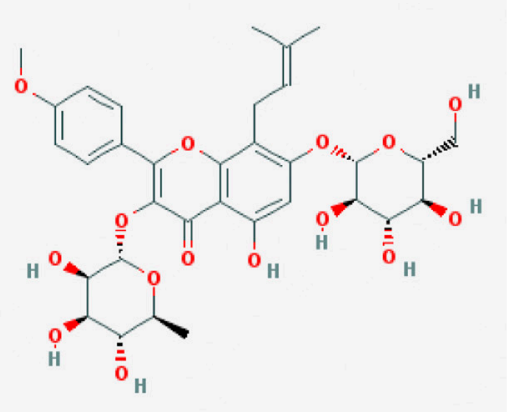

Icariin

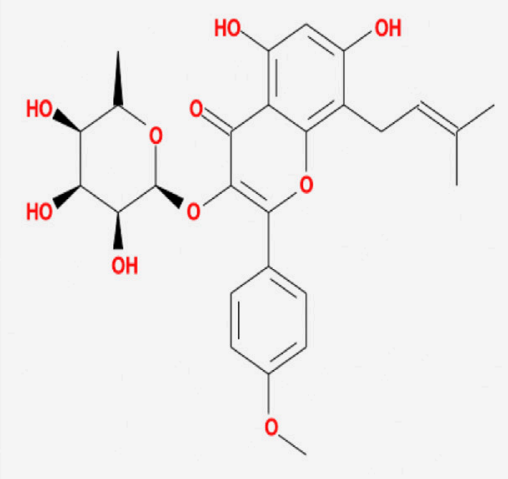

Icariside II

FIGURE 1 | Molecular structure of icariin and Icariside II.

Over the past decades, in vivo and in vitro experimental research into the use of Icariside II in the treatment of various cancers has been performed, showing the positive effects of Icariside II on cancers without systemic toxicity. Its antitumorigenic activity is mediated by induction of apoptosis and autophagy, triggering cancer cell cycle arrest, reducing cellular metabolism, and inhibition of metastasis and tumorinduced angiogenesis. Furthermore, Icariside II supplementation could enhance chemosensitivity and act synergistically and additively to current anticancer drugs, et al.

In this article, we aimed to review the anticancer properties of Icariside II in solid tumors, focusing on its underlying molecular mechanisms.

\section{TOXICITY AND PHARMACOKINETICS OF ICARISIDE II}

\section{In Vitro Anticancer Pharmacological Properties of Icariside II Apoptosis Induction}

Apoptosis is the most common type of programmed cell death, which depends on the activation of caspase proteases. Caspases, the primary mediators of apoptosis, are triggered by two main, interconnected pathways: the extrinsic and intrinsic pathways. The extrinsic pathway, also known as the receptor-mediated pathway, relies on the activation of death receptors (DRs) binding to their proapoptotic ligands on the cell membrane. This is defined as a transmembrane-receptor-mediated interaction in charge of transmitting the death signal from the cell surface to the intracellular area (Lee et al., 2020). The DRs are members of the tumor necrosis factor (TNF) receptor gene superfamily-TNF, FasL, and TNF-related apoptosis-inducing ligand (TRAIL), predominantly produced by immune cells, such as T cells, NK cells, macrophages, and dendritic cells (DC) (Goelz et al., 2021). When the DR is bound to the corresponding death ligand in the cell membrane, it triggers the recruitment of monomeric procaspase- 8 and integration of the deathinducing signaling complex (DISC), mainly comprising the FAS-associated death domain (FADD) or TNFR-associated death domain (TRADD). Once the DISC is formed, the autocatalytic processes of procaspase- 8 begin. Moreover, the interaction of procaspase- 8 with the DISC can also induce myristoylation of cytoplasmic $\mathrm{BH} 3$-interacting domain death agonist to promote apoptosis via one or the other of two distinct sub-pathways. In contrast, the intrinsic apoptotic pathway, also known as the mitochondrial pathway, is triggered by widespread mitochondrial outer membrane permeabilization (MOMP). This occurs after deadly apoptotic stresses such as DNA damage, cytokine deprivation, endoplasmic reticulum stress, and growth factor withdrawal. It is regulated by proapoptotic and antiapoptotic members of the BCL-2 family of proteins (Galluzzi et al., 2018). According to the number and structure of the BCL-2-homology (BH) domains, BCL-2 family proteins are categorized into three subgroups (BH1-4): the proapoptotic $\mathrm{BH} 3$-only proteins (e.g., BIM, NOXA, and BAD), the proapoptotic multidomain proteins (e.g., BAX and BAK), and the antiapoptotic proteins (e.g., BCL-2, BCL-XL, and MCL-1). Meanwhile, the proteins $\mathrm{BAX}$ and $\mathrm{BAK}$ provoke a release of cytochrome $c$ from the mitochondria into the cytoplasm and subsequently trigger the activation of caspase- 9 and downstream caspases such as caspase- 3 , caspase- 6 , and caspase- 7 , ultimately causing apoptosis.

Induction of tumor cell apoptosis is an approach and hot spot of tumor treatment. There is much evidence indicating that Icariside II exerts apoptosis-inducing effects in various cancer cell lines (Table 1; Figure 2). After exposure to Icariside II, the expression of cleavage of caspase-3/8/9/7/PARP and Bax increases in concentration- and time-dependent manners, but the antiapoptotic factor BCL-2 was decreased in human liver cancer cell lines (Guo et al., 2020a). In prostate cancer, Icariside II was shown to activate caspase-3, promote cytochrome $\mathrm{c}$ release 
TABLE 1 | Anticancer effects of Icariside I| in vitro.

\begin{tabular}{|c|c|c|c|c|c|c|}
\hline $\begin{array}{l}\text { Cell lines } \\
\text { used }\end{array}$ & & $\begin{array}{l}\text { Concentration } \\
\text { tested }\end{array}$ & $\begin{array}{l}\text { Efficacy, } \\
\text { IC50 } \\
\text { (exposure } \\
\text { time) }\end{array}$ & Anticancer effects & Molecular targets & References \\
\hline \multirow[t]{2}{*}{$\begin{array}{l}\text { Human liver cancer } \\
\text { cell }\end{array}$} & $\begin{array}{l}\text { HuH-7, } \\
\text { HepG2 }\end{array}$ & $20,50 \mu \mathrm{M}$ & $\begin{array}{l}\text { HuH-7: } \\
32 \mu \mathrm{M}(24 \mathrm{~h}) \\
\text { HepG2: } \\
34 \mu \mathrm{M}(24 \mathrm{~h})\end{array}$ & $\begin{array}{l}\text { Proapoptosis and inhibition of } \\
\text { proliferation, colony formation, } \\
\text { invasion, and migration }\end{array}$ & 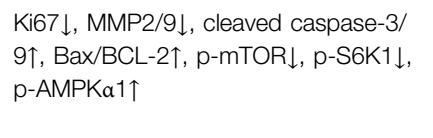 & $\begin{array}{l}\text { Guo et al. } \\
\text { (2020b) }\end{array}$ \\
\hline & HepG2 & $20,25,30 \mu \mathrm{M}$ & Unclear & $\begin{array}{l}\text { Proapoptosis and induction of } \\
\text { autophagy }\end{array}$ & 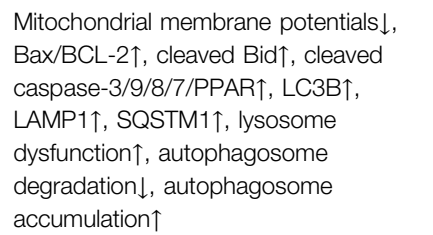 & $\begin{array}{l}\text { Geng et al. } \\
(2015)\end{array}$ \\
\hline \multirow[t]{2}{*}{$\begin{array}{l}\text { Human prostate } \\
\text { cancer }\end{array}$} & PC-3 & $10,20,40 \mu \mathrm{m}$ & $20 \mu \mathrm{M}(24 \mathrm{~h})$ & $\begin{array}{l}\text { Proapoptosis and arrest of cell } \\
\text { cycle }\end{array}$ & $\begin{array}{l}\text { Mitochondrial membrane potentials } \downarrow \text {, } \\
\text { Cyct } C \uparrow \text {, cleaved caspase-3/PPAR } \uparrow \\
\text { caspase-9 } 9 \text {, COX- } 2 \downarrow \text {, iNOS } \downarrow \text {, VEGF } \downarrow\end{array}$ & $\begin{array}{l}\text { Lee et al. } \\
(2009)\end{array}$ \\
\hline & DU145 & $20,40 \mu \mathrm{M}$ & Unclear & $\begin{array}{l}\text { Proapoptosis, arrest of cell cycle, } \\
\text { inhibition of invasion and } \\
\text { migration, and induction of } \\
\text { autophagy }\end{array}$ & 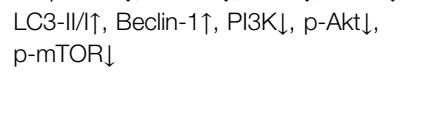 & Li et al. (2020) \\
\hline \multirow[t]{2}{*}{ Human glioma cells } & U251 & $20,50 \mu \mathrm{M}$ & Unclear & $\begin{array}{l}\text { Proapoptosis and inhibition of } \\
\text { proliferation, invasion, and } \\
\text { migration }\end{array}$ & 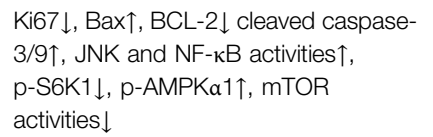 & $\begin{array}{l}\text { Guo et al. } \\
(2020 \mathrm{a})\end{array}$ \\
\hline & U87, A172 & $20,40 \mu \mathrm{M}$ & Unclear & $\begin{array}{l}\text { Proapoptosis, arrest of cell cycle, } \\
\text { and inhibition of proliferation, } \\
\text { migration, and invasion }\end{array}$ & $\begin{array}{l}\text { Cleaved caspase-3/PPAR } \uparrow \text {, Cyclin D } \downarrow \text {, } \\
\text { p53 } \uparrow \text {, Cyct C } \uparrow, \mathrm{p} 21 \uparrow, \mathrm{p} 27 \uparrow, \text { Akt } \\
\text { activities } \downarrow \text {, FOXO3a activity } \uparrow\end{array}$ & $\begin{array}{l}\text { Quan et al. } \\
(2017)\end{array}$ \\
\hline \multirow[t]{2}{*}{ Melanoma cells } & M14, MV3 & $20 \mu \mathrm{g} / \mathrm{ml}$ & Unclear & $\begin{array}{l}\text { Inhibition of proliferation and } \\
\text { migration }\end{array}$ & $\mathrm{miR}-144 \uparrow$ & $\begin{array}{l}\text { Peng and } \\
\text { Zhang (2018) }\end{array}$ \\
\hline & A375 & $25,50,100 \mu \mathrm{M}$ & Unclear & $\begin{array}{l}\text { Proapoptosis, inhibition of } \\
\text { proliferation, and arrest of cell } \\
\text { cycle }\end{array}$ & $\begin{array}{l}\text { CDK2 } \downarrow \text {, cyclin E } \downarrow, P-C D K 1 \downarrow \text { and cyclin } \\
\text { B1 } \downarrow, \text { ROS } \uparrow, p-p 53 \uparrow, p-p 38 \uparrow, p 21 \uparrow, \\
\text { cleaved PPAR } \uparrow\end{array}$ & $\begin{array}{l}\text { Wu et al. } \\
(2015)\end{array}$ \\
\hline $\begin{array}{l}\text { Human pancreatic } \\
\text { cancer cells }\end{array}$ & $\begin{array}{l}\text { PANC-1, } \\
\text { CFPAC-1 }\end{array}$ & $25,50 \mu \mathrm{M}$ & Unclear & $\begin{array}{l}\text { Proapoptosis and inhibition of } \\
\text { proliferation, migration, and } \\
\text { invasion }\end{array}$ & 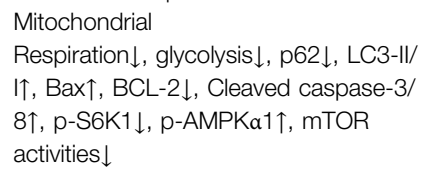 & Ni et al. (2019) \\
\hline \multirow[t]{2}{*}{$\begin{array}{l}\text { Human breast } \\
\text { cancer cells }\end{array}$} & MCF7 & $25,50,75 \mu \mathrm{M}$ & $50 \mu \mathrm{M}(72 \mathrm{~h})$ & Proapoptosis & 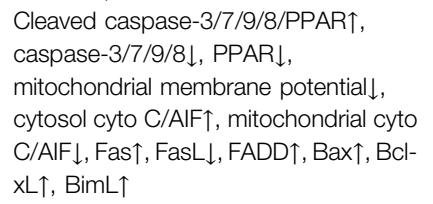 & $\begin{array}{l}\text { Huang et al. } \\
(2012)\end{array}$ \\
\hline & $\begin{array}{l}\text { MDA- } \\
\text { MB-231 }\end{array}$ & $6.25,12.5,25 \mu \mathrm{M}$ & Unclear & Inhibition of invasion & $\mathrm{CXCR} 4 \downarrow, \mathrm{NF}-\kappa \mathrm{B} \downarrow$ & $\begin{array}{l}\text { Kim and Park } \\
(2014)\end{array}$ \\
\hline $\begin{array}{l}\text { Human epidermoid } \\
\text { carcinoma cells }\end{array}$ & A431 & $10,25,50 \mu \mathrm{M}$ & Unclear & Proapoptosis & $\begin{array}{l}\text { Cleaved caspase-9/PPAR } \uparrow \text {, caspase } \\
\text { 9 } \downarrow \text {, PPAR } \downarrow \text {, AKT/STAT3/ERK } \\
\text { activities } \downarrow, \text { EGFR activities } \downarrow\end{array}$ & \\
\hline \multirow[t]{3}{*}{$\begin{array}{l}\text { Human cervical } \\
\text { cancer cells }\end{array}$} & Hela & $10,20,30 \mu \mathrm{M}$ & $9.2 \mu \mathrm{M}(48 \mathrm{~h})$ & $\begin{array}{l}\text { Arrest of cell cycle, inhibition of } \\
\text { proliferation, and proapoptosis }\end{array}$ & 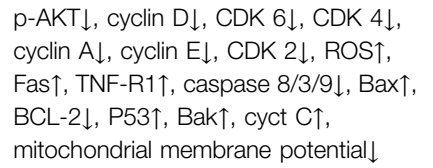 & $\begin{array}{l}\text { Sun et al. } \\
(2020 b)\end{array}$ \\
\hline & Hela & $5,10,20,30 \mu \mathrm{M}$ & Unclear & Inhibition of invasion and migration & 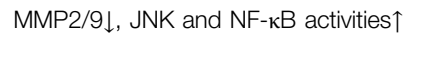 & $\begin{array}{l}\text { Sun et al. } \\
(2020 a)\end{array}$ \\
\hline & Hela & $6.25,12.5,25 \mu \mathrm{M}$ & Unclear & Inhibition of invasion & CXCR4 $\downarrow$, NF- $\kappa B \downarrow$ & $\begin{array}{l}\text { Kim and Park } \\
(2014)\end{array}$ \\
\hline $\begin{array}{l}\text { Human NSCLC } \\
\text { cells }\end{array}$ & A549 & $6.25,12.5,25 \mu \mathrm{M}$ & $\begin{array}{l}25.1 \mu \mathrm{M} \\
(24 \mathrm{~h}) \\
11.5 \mu \mathrm{M} \\
(48 \mathrm{~h}) \\
9.6 \mu \mathrm{M}(72 \mathrm{~h})\end{array}$ & Proapoptosis & 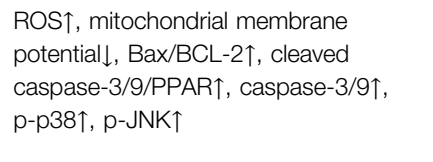 & $\begin{array}{l}\text { Song et al. } \\
\text { (2012) }\end{array}$ \\
\hline
\end{tabular}


TABLE 1 | (Continued) Anticancer effects of Icariside I| in vitro.

\begin{tabular}{|c|c|c|c|c|c|c|}
\hline $\begin{array}{l}\text { Cell lines } \\
\text { used }\end{array}$ & & $\begin{array}{l}\text { Concentration } \\
\text { tested }\end{array}$ & $\begin{array}{l}\text { Efficacy, } \\
\text { IC50 } \\
\text { (exposure } \\
\text { time) }\end{array}$ & Anticancer effects & Molecular targets & References \\
\hline $\begin{array}{l}\text { Human esophageal } \\
\text { cancer cell }\end{array}$ & Eca109 & $\begin{array}{c}12.5 \mu \mathrm{g} / \mathrm{ml}, 25 \mu \mathrm{g} / \\
\mathrm{ml}, 50 \mu \mathrm{g} / \mathrm{ml}\end{array}$ & $\begin{array}{l}24.8 \mu \mathrm{g} / \\
\mathrm{ml}(48 \mathrm{~h})\end{array}$ & $\begin{array}{l}\text { Proapoptosis and arrest of cell } \\
\text { cycle }\end{array}$ & Survivin $\downarrow$, Cyclin D1 $\downarrow, \beta$-catenin $\downarrow$ & $\begin{array}{l}\text { Wang et al. } \\
\text { (2011) }\end{array}$ \\
\hline \multirow[t]{2}{*}{$\begin{array}{l}\text { Human } \\
\text { osteosarcoma cells }\end{array}$} & $\begin{array}{l}\text { MG-63, } \\
\text { Saos-2 }\end{array}$ & $20,25,30 \mu \mathrm{M}$ & Unclear & Inhibition of proliferation & EGFR/mTOR activities $\downarrow$ & $\begin{array}{l}\text { Geng et al. } \\
(2014)\end{array}$ \\
\hline & HOS & $0.1,1,10 \mu \mathrm{M}$ & Unclear & $\begin{array}{l}\text { Suppression of cell growth and } \\
\text { inhibition of angiogenesis, } \\
\text { migration, invasion, and glucose } \\
\text { metabolism }\end{array}$ & $\begin{array}{l}\mathrm{HIF}-1 \alpha \downarrow, \mathrm{VEGF} \downarrow, \mathrm{UPAR} \downarrow, \mathrm{ADM} \downarrow \\
\mathrm{MMP} 2 \downarrow \text {, aldolase } \mathrm{A} \downarrow \text {, and enolase } 1 \downarrow\end{array}$ & $\begin{array}{l}\text { Choi et al. } \\
\text { (2008) }\end{array}$ \\
\hline
\end{tabular}

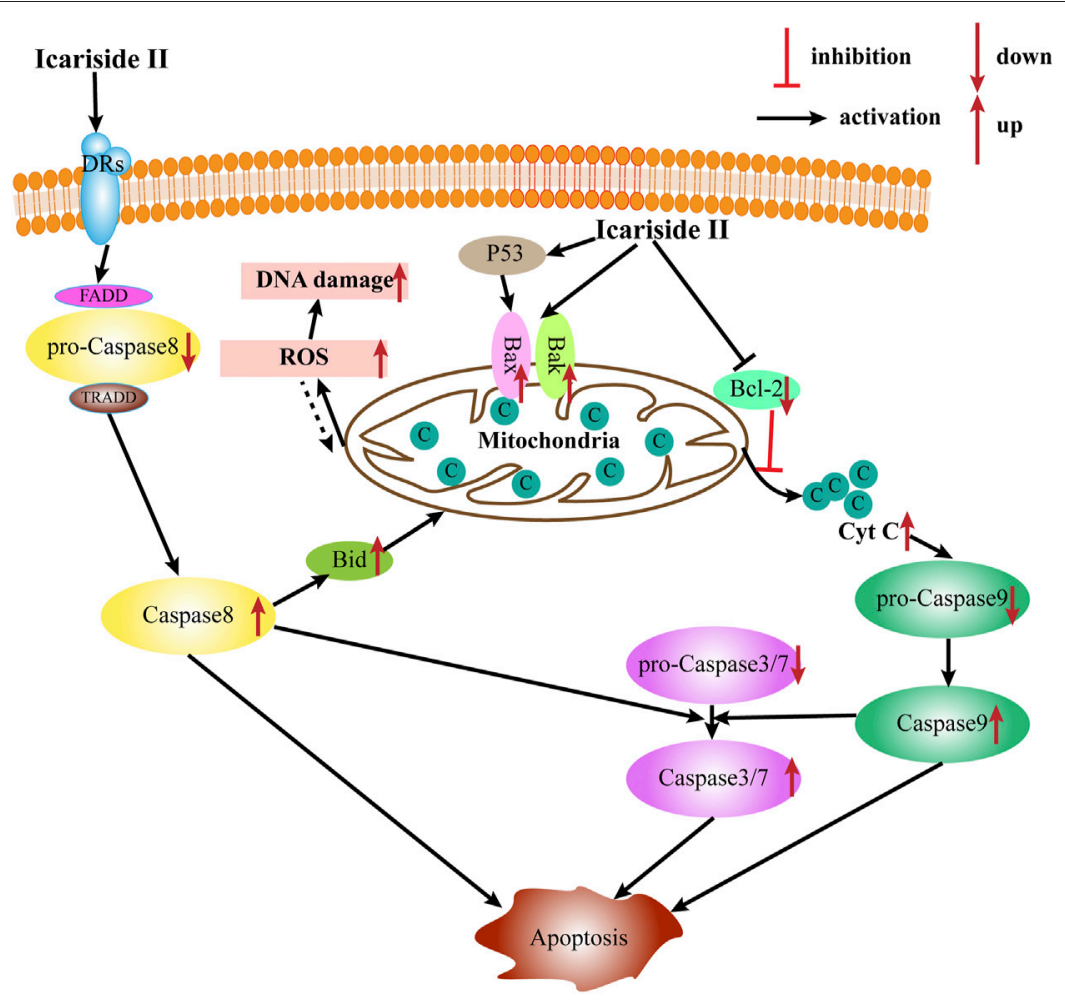

FIGURE 2 | Apoptosis induction by lcariside I| intrinsic and extrinsic pathways.

into cytosol, and simultaneously reduce the expression of the inactive, proenzymatic form of caspase- 9 (Lee et al., 2009). The apoptotic mechanism in human glioma cells is activated by elevating the cleavage of caspase-3/8, BCL-2-associated protein (Bax), cytochrome c, and reducing the BCL-2 level (Quan et al., 2017; Guo et al., 2020b). Human melanoma cells displayed morphological changes indicative of the early apoptotic stage when treated with Icariside II and a remarkable elevation was seen in the expression of the cleavage of caspase- 3 and PPAR (Wu et al., 2012; Peng and Zhang, 2018). Another study also showed that the ratio of $\mathrm{Bax}$ to $\mathrm{BCL}-2$ proteins increased in a concentration- and time-dependent manner in pancreatic cancer (Ni et al., 2019). Its proapoptotic effect was also demonstrated in breast cancer and non-melanoma skin cancer, where Icariside II induced the release of cytochrome $c$ through the mitochondrial membrane to the cytosol, subsequently leading to the activation of caspase-3/7/9 and PARP cascade (Huang et al., 2012; Wu et al., 2013). In a recent study, Icariside II was shown to inhibit the growth of cervical cancer HeLa cells and induce apoptosis through improving caspase-3/9 activity, p53, cytochrome c expression, and modulate the BCL-2 family of proteins (Sun et al., 2020a). Altogether, a body of evidence supports the idea that Icariside II has powerful proapoptotic activity through the intrinsic apoptosis pathway, and there is no data indicating the influence of Icariside II on apoptosis mediated by the extrinsic pathway. 


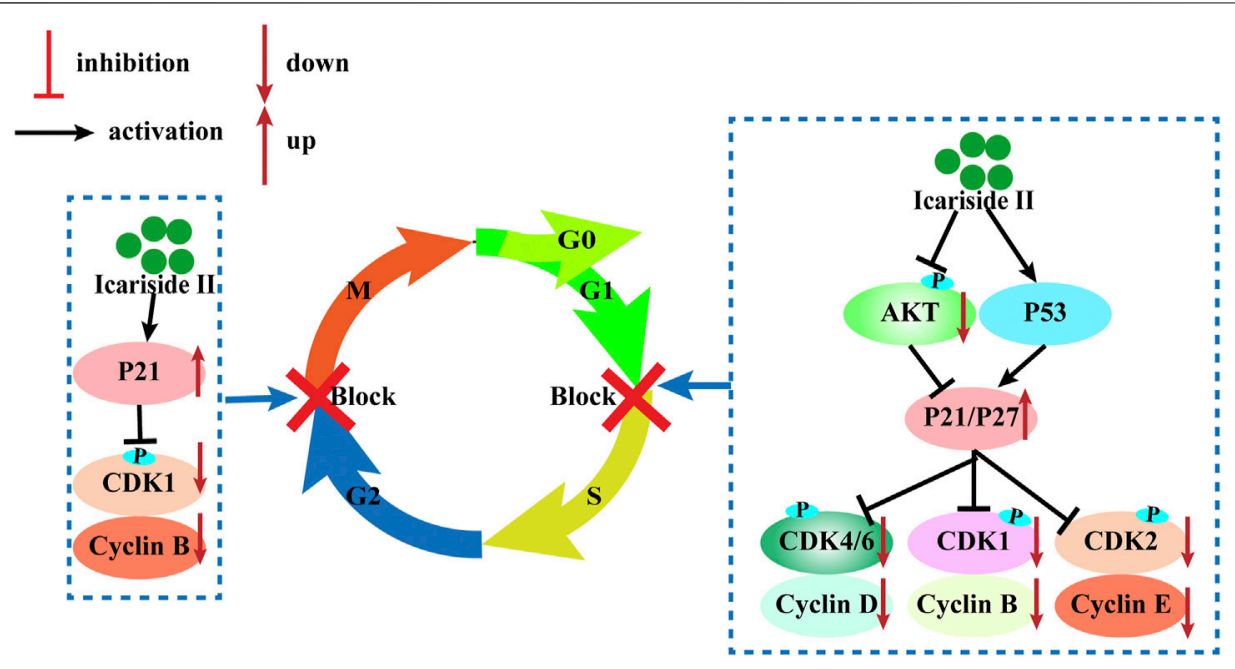

FIGURE 3 | Cell cycle arrest induced by lcariside II.

Increased reactive oxygen species (ROS) production is detected when oxidative stress occurs. Although ROS are mainly generated in mitochondria, they can cause oxidative damage to mitochondrial DNA, proteins, and lipids, which affect the BCL-2 family of proteins and cytochrome c, ultimately triggering apoptosis via the intrinsic and extrinsic pathways (Groeger et al., 2009). Icariside II could induce apoptosis via the overproduction of ROS, while NAC, a scavenger of ROS, diminished the effect in human non-smallcell lung cancer (NSCLC) (Song et al., 2012).

\section{Cell Cycle Arrest}

The cell cycle consists of four sequential phases: the G1, S, G2, and $\mathrm{M}$ phases. The first step is called the G1 phase, and it is vital for cell proliferation and sensitive to growth signaling networks; the S phase is a time for DNA synthesis and its complete duplication; $\mathrm{G} 2$, the gap phase, is when the cell prepares for entry into mitosis; the $\mathrm{M}$ phase is when the cell divides into two genomically stable daughter cells (Mansilla et al., 2020). The cell cycle is tightly regulated by cyclin-dependent kinases (CDKs) that coordinate with their cyclin partners (Mansilla et al., 2020). Uncontrolled CDK activity is frequently seen in cancer cells and cyclindependent kinase inhibitors (CKIs) possess antitumor properties by restricting the kinase activity. Therefore, inhibition of CDK activity is an effective strategy to inhibit cancer.

Icariside II has been investigated for inducing cell cycle arrest (Figure 3). In human glioblastoma cells, Icariside II induced G0/ G1 cell cycle arrest by downregulating G1/S transition cyclin D whilst upregulating cyclin-dependent kinase inhibitors p21 and p27, dependent on the Akt-FOXO3a pathway. Likewise, Icariside II increased the percentage of A375 human melanoma cells at the G0/G1 boundary with downregulations of cyclin E, cyclin B1, CDK2, and phosphorylated-CDK1 (p-CDK1) (Wu et al., 2015). Besides the inhibition of G1/S phase cell cycle regulatory proteins, Icariside II could also trigger cell cycle arrest through the generation of ROS by activating the $3 \mathrm{M}$ MAPK and p53 signaling pathways (Wu et al., 2015). In human esophageal squamous carcinoma Eca109 cells, Icariside II was demonstrated to be highly effective in downregulating $\beta$-catenin and cyclin D1 protein expression and stochastically inducing cell cycle arrest (Wang et al., 2011). The cell cycle blockage in human PC-3 and DU145 prostate cancer cells at the G0/G1 checkpoint was caused by Icariside II in a dose-dependent manner, which increased the percentage of cells undergoing G1 phase cell cycle arrest to $45.7-80 \%$ upon treatment with $40 \mu \mathrm{M}$ (Lee et al., 2009; Li et al., 2020). These results were supported in a study by Wei $\mathrm{Z}$, which showed that Icariside II induced significant accumulation of cells at the G1/G0 phase with decreased cell populations at the $S$ phase and the G2/M phase in cervical cancer (Sun et al., 2020). This is attributed to the downregulation of $\mathrm{p}-\mathrm{AKT}, \mathrm{CDK} 2$, and cyclin $\mathrm{E}$ but no changes in cyclin D, CDK6, and cyclin A expressions (Sun et al., 2020a). These studies have presented evidence that Icariside II-induced cell cycle arrest of cancer cells predominantly occurs during the G0/G1 phase by modulating the expressions and kinase activities of cyclin, CDKs, p21, p53, and other signaling pathways.

\section{Autophagy Triggering}

Autophagy is a physiological cellular process, whereby misfolded proteins, damaged or aged organelles, and mutated proteins are degraded, fused with lysosomes, and generate the autolysosome (Behrends et al., 2010). It is hallmarked by a lysosome-dependent process and predominately regulated by autophagy-related genes (ATG). The process is divided into four steps in a given order: initiation, nucleation, maturation, and degradation, all of which are controlled by different ATG proteins (Mercer et al., 2018). Several molecules are involved in autophagic processes; these include mammalian target of rapamycin (mTOR), AMPactivated protein kinase (AMPK), Beclin-1, autophagy-related proteins and microtubule-associated protein 1 light chain 3 (LC3), etc. (Mercer et al., 2018). Autophagy has dichotomous 
roles in tumor promotion and suppression. In the early stages of cancer progression, autophagy acts as a tumor suppressor by removing damaged proteins and organelles, inhibiting inflammation, limiting genomic instability, inducing stress, and suppressing ROS production by the mitochondria (Lim and Murthy, 2020; Yun et al., 2020). In contrast, when tumors are already established, autophagy promotes cancer cell survival and growth by reprogramming metabolism, promoting angiogenesis, and promoting hypoxia and oxidative stress (Das et al., 2018; Thomas et al., 2018). Given that autophagy plays a role in enhancing tumor cell death, initiation of autophagy may be an attractive strategy for anticancer therapies.

Icariside II, as a novel phosphodiesterase 5 inhibitor, was found to play a role in regulating autophagy via the PI3K/AKT/ mTOR, ROS/GSK-3 $\beta /$ mitochondrial, and PKG/GSK-3 $\beta$ signaling pathways in different diseases (Gao et al., 2017; Gao et al., 2020; Li et al., 2020; Zhang et al., 2020). In human prostate cancer, autophagy induced by Icariside II was characterized by enhanced autophagosome formation, reduction in P70S6K expression, and upregulation of LC3 and Beclin-1 by inhibiting PI3K-AKT-mTOR activity (Li et al., 2020). Till date, the influence of Icariside II on autophagy in different cancer cell lines is not well elucidated and more studies are needed to shed better light on this subject.

\section{Inhibition of Cancer Cell Metastasis}

Metastasis is the leading cause of morbidity and mortality in cancer patients (Kudo-Saito et al., 2021). It is a multistep process through which cancer cells spread from the primary tumor to the bloodstream, lymphatic system, or distant parts of the body. It involves four steps: detachment, migration, invasion, and formation. In most cases, there is no effective therapy for metastatic cancer, and metastasis is regarded as a predictor of the worst prognosis in cancer development. Hence, inhibition of metastasis is an enormous challenge for clinicians and of vital importance to control cancer and prolong patients' overall survival. Several molecular mechanisms are closely correlated with metastasis, such as epithelial-mesenchymal transition (EMT), angiogenesis, and extracellular matrix (ECM) degradation (Majidpoor and Mortezaee, 2021). EMT plays an especially key role in metastasis of cancer cells. Matrix metalloproteinases (MMPs), as zinc-dependent endopeptidases, are able to catalyze the proteolytic activities and induce degradation of the ECM. Specifically, MMP-2 and MMP-9, whose catalytic domains are unique to fibronectin type II, are necessary for gelatin digestion and favor tumorigenic processes. Compared with nonmalignant tissue, the levels of MMP-2 and MMP-9 expression are higher in tumors (Scheau et al., 2019; Majidpoor and Mortezaee, 2021). Moreover, some chemokines and their receptors are reported to be closely linked to the metastasis of cancers. These include CXC chemokine ligand (CXCL) 12 and its receptor, CXCR4 (Yang et al., 2015; Nguyen et al., 2020). The level of CXCL12 is higher in metastatic sites (Balkwill, 2004).

Accumulating evidence is indicating that Icariside II has the ability to control cancer cell invasion and migration in lung cancer (Song et al., 2017), hepatocellular carcinoma (Guo et al., 2020a), cervical cancer (Sun et al., 2020b), osteosarcoma (Choi et al., 2008), melanoma (Peng and Zhang, 2018), and prostate cancer (Li et al., 2020). In hepatocellular carcinoma (Guo et al., 2020b) and cervical cancer (Sun et al., 2020a), it has been demonstrated that Icariside II could weaken the migratory and invasive ability of HuH-7, HepG2, and HeLa cells through inhibiting metastasis-related protein MMP2/9 expression. CXCR4 is expressed on human cervical cancer HeLa cells and breast cancer MDA-MB-231 cells. Under the conditions of Icariside II treatment, this expression of CXCR4 is suppressed by inhibiting NF- $\kappa \mathrm{B}$ activation (Kim and Park, 2014). In addition, the MAPK signaling pathway, including P38 MAPK, ERK, and JNK, participated in Icariside II regulation (Sun et al., 2020b). It is a well-established fact that an active inflammatory microenvironment created by immune cells and inflammatory cytokines is favorable for cancer invasion and metastasis by modulating EMT (Ma et al., 2016; Yan et al., 2018). Similarly, in lung cancer, the results of wound healing and the transwell assay indicated that IL- 6 and TNF- $\alpha$ contribute remarkably to wound closure and cell invasion. These effects were partially reversed by Icariside II through upregulating E-cadherin and downregulating $\mathrm{N}$-cadherin and Vimentin via inactivation of the Akt/NF-kB/GSK-3 $\beta$ pathway (Song et al., 2017). Apart from these, in a study with human osteosarcoma cells, Icariside II suppressed cancer cell metastasis by decreasing the protein level of HIF-1 $\alpha$ and simultaneously inducing a decrease in HIF-inducible genes, which are closely associated with angiogenesis and glucose metabolism (Choi et al., 2008). The molecular mechanisms used by Icariside II involved the inhibition of the vascular endothelial growth factor (VEGF), the urokinase plasminogen activator receptor (uPAR), adrenomedullin (ADM), MMP2, aldolase A, and enolase 1 (Choi et al., 2008).

\section{Inhibition of Angiogenesis}

Blood vessel walls are composed of endothelial cells (ECs) and mural cells. Tumor-associated vessels are significantly different from physiological ones and are characterized by rapid formation, disorganized structure, and high permeability (Ribatti et al., 2000). New vessels begin to form when a tumor grows; they provide cancer cells with nutrients, oxygen, and growth factors. Moreover, cancer-associated vessels regulate the entrance and egress of circulating leukocytes or other immune cells through chemokines and other molecules on the endothelial cell surface (Baeriswyl and Christofori, 2009). Thus, angiogenesis plays a crucial role in tumor growth, invasion, migration, and tumor immune surveillance. The VEGF is deemed a pivotal mediator that stimulates the pro-angiogenic activity; thus, anti-angiogenic therapy, especially anti-VEGF or VEGF antagonist therapy, is a common strategy for combined therapy in cancer treatment (Teleanu et al., 2019; Guo and Cui, 2020). Tumor-hypoxia contributes to angiogenesis via upregulating VEGF and VEGF receptors. Concerning HOS osteosarcoma cells, Icariside II attenuated the positive effect of HIF on VEGF expression (Choi et al., 2008). The tube formation assay showed that Icariside II broke the endothelial network-like structures induced by HIF (Choi et al., 2008). It is necessary to go 
TABLE 2 | Efficacy of Icariside || in combinational cancer therapy.

\begin{tabular}{|c|c|c|c|c|c|c|}
\hline $\begin{array}{l}\text { Cell lines } \\
\text { used }\end{array}$ & & $\begin{array}{l}\text { Concentration } \\
\text { used }(\mu \mathrm{M})\end{array}$ & Drugs & Effects & Molecular targets & References \\
\hline $\begin{array}{l}\text { Human melanoma } \\
\text { cells }\end{array}$ & A375 & 10 & Paclitaxel & Proapoptosis & 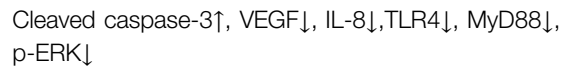 & $\begin{array}{l}\text { Wu et al. } \\
(2012)\end{array}$ \\
\hline $\begin{array}{l}\text { Human melanoma } \\
\text { cells }\end{array}$ & A375 & 20 & $\begin{array}{l}\text { Recombinant } \\
\text { TRAIL }\end{array}$ & Proapoptosis & $\begin{array}{l}\text { ROS } \uparrow \text {, caspase-3/8/9 } \downarrow \text {, PARP } \downarrow \text {, cFLIP } \downarrow \text {, STAT3/AKT } \\
\text { activity } \downarrow, N F-\kappa B \text { activity } \downarrow\end{array}$ & Du et al. (2016) \\
\hline
\end{tabular}

one step further to explore the anti-angiogenic properties of Icariside II in cancers.

\section{Adjutant Therapy}

Even though chemotherapy, combined with radiotherapy, targeted therapy, and immunotherapy, is a conventional therapy for many cancers, the clinical outcomes remain unsatisfactory, with issues such as drug-induced multi-drug resistance (MDR), serious adverse effects, and poor therapeutic response (Burrell et al., 2013). Combination therapy is considered a good therapeutic strategy for improving therapeutic efficacy and tackling MDR. Effort has been put into finding nonchemotherapeutic drugs, such as natural products, for improving anticancer efficacy and outcomes of combination therapy and, to some extent, reducing toxic side effects.

Icariside II, as a kind of natural product, has not only exhibited antitumor activities applied as a single agent but also contributes to a synergistic effect with chemotherapeutic drugs for malignant melanoma (Wu et al., 2012; Table 2). Paclitaxel is one of the most important cancer chemotherapeutic drugs and is widely used for the treatment of various cancers. The TLR4 signal, combined with its adaptor protein MyD88, could activate its downstream ERK, $\mathrm{P} 38$, or JNK and then promote tumor growth, metastasis, and chemoresistance (Guha et al., 2001). MyD88 is a potent biomarker for predicting paclitaxel response (Silasi et al., 2006). Icariside II treatment leads to the improvement of the paclitaxel-induced apoptosis by inhibiting the TLR4/MyD88/ ERK signaling pathway in human melanoma A375 cells (Wu et al., 2012). The tumor necrosis factor-related apoptosisinducing ligand (TRAIL/Apo2L) is a promising agent for triggering apoptosis while some cancer cells with overexpression of FLICE-like inhibitory protein (cFLIP) are resistant to it (Kataoka, 2005). Icariside II can reverse the drug resistance in A375 melanoma cells by downregulating the expressions of cFLIP mediated by the ROS-STAT3 or NF- $\kappa \mathrm{B}$ signaling pathways (Du et al., 2016).

\section{In Vivo Therapeutic Potential of Icariside II}

There is much evidence indicating that Icariside II inhibits growth, invasion, and migration and prevents drug resistance in cancer cells in vitro. The anticancer potential of Icariside II has also been demonstrated in in vivo investigations. Nude mice xenografts, established using HCC cells, were treated with $25 \mathrm{mg} / \mathrm{kgd}$ Icariside II for 30 days and exhibited a remarkable reduction in tumor volume, weight, and the protein levels of MMP2/9 and BCL-2/Bax ratio compared to the DMSO-treated group (Guo et al., 2020a). The antitumor effects of Icariside II on reducing tumor weight and volume have been verified in other animal models such as HeLa-bearing mice (Sun et al., 2020a), sarcoma-180 tumor ICR mice (Geng et al., 2014), M14 xenograft B-NSG nude mice (Peng and Zhang, 2018), a U251 human xenograft model (Guo et al., 2020b), BALB/c mice with four $\mathrm{T}^{1}$-Neu cells (Zhou et al., 2011), and an Eca109 xenograft model (Wang et al., 2011). In these reports, the anticancer efficiency of Icariside II is achieved through inhibiting cellular proliferation (Geng et al., 2014), enhancing cell apoptosis (Guo et al., 2020a), blocking the cell cycle (Wang et al., 2011), and modifying the inflammatory microenvironment (Zhou et al., 2011). The detailed information is presented in Table 3. Moreover, Icariside II not only inhibits tumor growth and metastasis but also causes no adverse effects on the body; this was confirmed by a study (Sun et al., 2020b) in which the body weight and main organ weight showed no changes.

\section{Approaches to Strengthen Icariside II Absorption and Delivery}

Animal and cell experiments have provided evidence that Icariside II is a potential chemopreventive agent. Unfortunately, Icariside II possesses low oral absorption due to its poor aqueous solubility, permeability, and efflux, which restricts its clinical application. Therefore, it is essential to develop a formulation for Icariside II to increase its solubility and absorption and improve its therapeutic effects (Table 4).

Phospholipids are an important component of the cell membrane and promote drug absorption. Phospholipid complex has been used for resolving oral bioavailability-related issues. A study showed that Icariside IIphospholipid complex (a nanoscale size, $81 \pm 10 \mathrm{~nm}$ ) resulted in a significant elevation of absorptive permeability and a dramatic decrease in efflux ratio in vitro and a higher relative bioavailability in vivo (Jin et al., 2012). The maximum concentration and time to maximum concentration were significantly higher in the baohuoside I group $(296.32 \mathrm{ng} / \mathrm{ml}$ vs. $525.37 \mathrm{ng} / \mathrm{m}, 50$ vs. $52.5 \mathrm{~min}$ ) (Jin et al., 2012). Even though phospholipid complexes made obvious contributions to gastrointestinal absorption, their solubility is low which also limits their application. D-a-tocopheryl polyethylene glycol 1,000 succinate (Vitamin E TPGS), or TPGS, is a water-soluble derivative of natural vitamin $\mathrm{E}$ and has been extensively used as a carrier for enhancing drug solubility, permeability, and a sustained, 
TABLE 3 | Therapeutic potential of Icariside II in vivo.

\begin{tabular}{|c|c|c|c|c|c|c|c|}
\hline Cancer type & $\begin{array}{l}\text { Animal } \\
\text { subject }\end{array}$ & Model & Dose & Days & $\begin{array}{c}\text { Route of } \\
\text { administration }\end{array}$ & $\begin{array}{l}\text { Results and mechanisms } \\
\text { of action }\end{array}$ & Reference \\
\hline Live & $\begin{array}{l}\text { Male BALB/c } \\
\text { nude mice }\end{array}$ & Subcutaneously & $25 \mathrm{mg} / \mathrm{kg} \cdot \mathrm{d}$ & 30 & $\begin{array}{l}\text { Intragastric } \\
\text { administration }\end{array}$ & $\begin{array}{l}\text { Reduction of tumor volume and tumor weight } \\
\text { and downregulation of MMP-2, MMP9, BCL- } \\
2 \text {, and p-mTOR while upregulation of bax } \\
\text { expressions }\end{array}$ & Guo et al. (2020b) \\
\hline Cervical & $\begin{array}{l}\text { Female } \\
\text { BALB/c nude } \\
\text { mice }\end{array}$ & Subcutaneously & $25 \mathrm{mg} / \mathrm{kg} \cdot \mathrm{d}$ & 12 & Vein injection & $\begin{array}{l}\text { Reduction of tumor volume and weight by } \\
\text { inducing cell apoptosis and downregulation } \\
\text { of MMP2/9 }\end{array}$ & $\begin{array}{l}\text { Sun et al. (2020a); } \\
\text { Sun et al. (2020b) }\end{array}$ \\
\hline Osteosarcoma & $\begin{array}{l}\text { Male ICR } \\
\text { mice }\end{array}$ & Subcutaneously & $\begin{array}{l}10,20, \text { and } \\
30 \mathrm{mg} / \mathrm{kg} \cdot \mathrm{d}\end{array}$ & 10 & $\begin{array}{l}\text { Intraperitoneal } \\
\text { injection }\end{array}$ & $\begin{array}{l}\text { Inhibition of cell proliferation via the EGFR/ } \\
\text { mTOR signaling pathway and } \\
\text { downregulation } \\
\text { of Ki-67 expression }\end{array}$ & Geng et al. (2014) \\
\hline Melanoma & $\begin{array}{l}\text { Female } \\
\text { B-NSG nude } \\
\text { mice }\end{array}$ & Subcutaneously & $\begin{array}{l}25 \mathrm{mg} / \mathrm{kg} \text {, every } \\
\text { two days }\end{array}$ & 20 & Vein injection & Reduction of tumor size and weight & $\begin{array}{l}\text { Peng and Zhang } \\
\text { (2018) }\end{array}$ \\
\hline Glioma & $\begin{array}{l}\text { Male BALB/c } \\
\text { nude mice }\end{array}$ & Subcutaneously & $35 \mathrm{mg} / \mathrm{kg} \cdot \mathrm{d}$ & 30 & $\begin{array}{l}\text { Intraperitoneal } \\
\text { injection }\end{array}$ & $\begin{array}{l}\text { Inhibition of tumor volume and tumor weight } \\
\text { through the mTOR/AMPKa signal pathway }\end{array}$ & Guo et al. (2020a) \\
\hline Breast & $\begin{array}{l}\text { Female } \\
\text { BALB/c mice }\end{array}$ & Subcutaneously & $\begin{array}{l}100 \mathrm{mg} / \mathrm{kg} \text {, three } \\
\text { times a week }\end{array}$ & 28 & $\begin{array}{l}\text { Intraperitoneal } \\
\text { injection }\end{array}$ & $\begin{array}{l}\text { Reduction of tumor volume and decreasing } \\
\text { number of } \mathrm{Gr}-1^{+} \mathrm{CD} 11 \mathrm{~b}^{+} \mathrm{MDSC} \text { in the } \\
\text { spleen }\end{array}$ & Zhou et al. (2011) \\
\hline Esophagus & $\begin{array}{l}\text { Female } \\
\text { BALB/c nude } \\
\text { mice }\end{array}$ & Subcutaneously & $\begin{array}{l}25 \mathrm{mg} / \mathrm{kg} \text {, every } \\
\text { two days }\end{array}$ & 21 & $\begin{array}{l}\text { Intralesional } \\
\text { injection }\end{array}$ & Reduction of tumor size & Wang et al. (2011) \\
\hline
\end{tabular}

TABLE 4 | Application of drug delivery systems in Icariside II.

\begin{tabular}{|c|c|c|c|}
\hline & Model & Results & Reference \\
\hline Phospholipid & $\begin{array}{l}\text { Caco- } 2 \text { cell monolayer; } \\
\text { male rats }\end{array}$ & $\begin{array}{l}\text { Absorptive permeability, secretory permeability } \uparrow \text {, efflux ratio } \downarrow \text {, maximum concentration } \uparrow \text {, time } \\
\text { to maximum concentration } \downarrow \text {, relative bioavailability } \uparrow\end{array}$ & Jin et al. (2012) \\
\hline Phospholipid + TPGS & $\begin{array}{l}\text { Caco- } 2 \text { cell monolayer; } \\
\text { male rats }\end{array}$ & $\begin{array}{l}\text { Solubility } \uparrow \text {, instantaneous release } \uparrow \text {, permeability } \uparrow \text {, efflux ratios } \downarrow \text {, maximum concentration } \uparrow \text {, } \\
\text { time to maximum concentration } \downarrow \text {, relative bioavailability } \uparrow\end{array}$ & Jin et al. (2013) \\
\hline TPGS + Solutol HS 15 & A549 cells & $\begin{array}{l}\text { Solubility } \uparrow \text {, cellular uptake } \uparrow \text {, half-maximal inhibitory concentration } \downarrow \text {, toxic effects } \downarrow \text {, antitumor } \\
\text { efficiency } \uparrow\end{array}$ & $\begin{array}{l}\text { Yan et al. } \\
(2016)\end{array}$ \\
\hline $\begin{array}{l}\text { Solutol HS15 + Pluronic } \\
\text { F127 }\end{array}$ & $\begin{array}{l}\text { Caco- } 2 \text { cell monolayer; } \\
\text { male rats }\end{array}$ & $\begin{array}{l}\text { Solubility } \uparrow \text {, instantaneous release } \uparrow \text {, cellular uptake } \uparrow \text {, efflux ratios } \downarrow \text {, relative bioavailability } \uparrow, \text { no } \\
\text { apparent toxicity (-) }\end{array}$ & Jin et al. (2012) \\
\hline
\end{tabular}

controlled, and targeted drug delivery (Shah and Banerjee, 2011). The data collected by Xiao-Bin Jia et al. showed that TPGS/ Icariside II-phospholipid complex (at a ratio of 9:1) appears to result in a faster absorption rate, higher plasma concentration, longer circulation time, an increase in cellular uptake of drugs, and reduction of efflux in vitro and in vivo (Jin et al., 2013). Another way to enhance the anticancer activities is to pack Icariside II with TPGS and Solutol HS 15 (BTSM). Solutol HS 15 is a novel amphiphilic surfactant with many advantages, such as high solubility capacity, biocompatibility, and performance and low adverse effects (Yan et al., 2016). Icariside II in the presence of BTSM is more effective than Icariside II alone in inhibiting NSCLC cell proliferation and reducing tumor weight and volume in the NSCLC mice model (Yan et al., 2016). Similar results were obtained in mixed micelles, in which solutol HS15 and pluronic F127 were used as surfactants (Hou et al., 2016). Its solubility peaked to $11.7 \mathrm{mg} / \mathrm{ml}$, increasing up to 900 fold while the efflux ratio decreased by $83.5 \%$ in Caco- 2 cell culture models (Hou et al., 2016). In addition, BTSM demonstrates the properties of increasing the relative bioavailability, which increased about 3- fold $(4,059.81 \mathrm{mg} / \mathrm{l} \cdot \mathrm{h}$ vs. $12,886.76 \mathrm{mg} / \mathrm{l} \cdot \mathrm{h})$ with gastrointestinal safety in rats (Hou et al., 2016).

\section{CONCLUSION}

Malignancy is a global health problem that is threatening people's lives. Even though new therapeutic approaches have been developed and introduced for cancer treatment, the overall cure rate remains unsatisfactory, and adverse events are a critical obstacle to clinical application. Therefore, there is still a need for new drugs and treatment strategies against cancer. Icariside II has been found to have positive effects on multiple types of cancers in numerous studies. In addition, Icariside II exerts synergistic effects when combined with chemotherapeutic drugs, such as paclitaxel, and other agents, such as TRAIL. However, it is not clear whether Icariside II has the potential to reduce the adverse effects of other therapies. Therefore, further in vivo and in vitro studies are required to assess the efficacy and safety of Icariside II for chemoprevention and treatment of cancers. 


\section{AUTHOR CONTRIBUTIONS}

FX wrote the original draft; QW made the tables; LL and JG reviewed the relevant literature; $\mathrm{RH}$ checked the language; and WC edited the draft and made revisions.

\section{REFERENCES}

Ambekar, R. S., and Kandasubramanian, B. (2019). A polydopamine-based platform for anti-cancer drug delivery. Biomater. Sci. 7 (5), 1776-1793. doi:10.1039/c8bm01642a

Baeriswyl, V., and Christofori, G. (2009). The angiogenic switch in carcinogenesis. Semin. Cancer Biol. 19 (5), 329-337. doi:10.1016/j.semcancer.2009.05.003

Balkwill, F. (2004). The significance of cancer cell expression of the chemokine receptor CXCR4. Semin. Cancer Biol. 14 (3), 171-179. doi:10.1016/j.semcancer.2003.10.003

Behrends, C., Sowa, M. E., Gygi, S. P., and Harper, J. W. (2010). Network organization of the human autophagy system. Nature 466 (7302), 68-76. doi:10.1038/nature09204

Bishayee, A., and Sethi, G. (2016). Bioactive natural products in cancer prevention and therapy: progress and promise. Semin. Cancer Biol. 40-41, 1-3. doi:10.1016/ j.semcancer.2016.08.006

Burrell, R. A., McGranahan, N., Bartek, J., and Swanton, C. (2013). The causes and consequences of genetic heterogeneity in cancer evolution. Nature 501 (7467), 338-345. doi:10.1038/nature12625

Choi, H. J., Eun, J. S., Kim, D. K., Li, R. H., Shin, T. Y., Park, H., et al. (2008). Icariside II from Epimedium koreanum inhibits hypoxia-inducible factor-1 $\alpha$ in human osteosarcoma cells. Eur. J. Pharmacol. 579 (1-3), 58-65. doi:10.1016/j. ejphar.2007.10.010

Das, C. K., Mandal, M., and Kögel, D. (2018). Pro-survival autophagy and cancer cell resistance to therapy. Cancer Metastasis Rev. 37 (4), 749-766. doi:10.1007/ s10555-018-9727-z

Du, J., Wu, J., Fu, X., Kai-Wing Tse, A., Li, T., Su, T., et al. (2016). Icariside II overcomes TRAIL resistance of melanoma cells through ROS-mediated downregulation of STAT3/cFLIP signaling. Oncotarget 7 (32), 52218-52229. doi:10.18632/oncotarget.10582

Galluzzi, L., Vitale, I., Aaronson, S. A., Abrams, J. M., Adam, D., Agostinis, P., et al. (2018). Molecular mechanisms of cell death: recommendations of the nomenclature committee on cell death 2018. Cell Death Differ 25 (3), 486-541. doi:10.1038/s41418-017-0012-410.1038/s41418-018-0102-y

Gao, J., Deng, Y., Yin, C., Liu, Y., Zhang, W., Shi, J., et al. (2017). Icariside II , a novel phosphodiesterase 5 inhibitor, protects against $\mathrm{H} 2 \mathrm{O} 2$-induced PC 12 cells death by inhibiting mitochondria-mediated autophagy. J. Cell. Mol. Med. 21 (2), 375-386. doi:10.1111/jcmm.12971

Gao, J., Long, L., Xu, F., Feng, L., Liu, Y., Shi, J., et al. (2020). Icariside II, a phosphodiesterase 5 inhibitor, attenuates cerebral ischaemia/reperfusion injury by inhibiting glycogen synthase kinase- $3 \beta$-mediated activation of autophagy. Br. J. Pharmacol. 177 (6), 1434-1452. doi:10.1111/bph.14912

Geng, Y. D., Yang, L., Zhang, C., and Kong, L. Y. (2014). Blockade of epidermal growth factor receptor/mammalian target of rapamycin pathway by Icariside II results in reduced cell proliferation of osteosarcoma cells. Food Chem. Toxicol. 73, 7-16. doi:10.1016/j.fct.2014.08.002

Geng, Y. D., Zhang, C., Shi, Y. M., Xia, Y. Z., Guo, C., Yang, L., et al. (2015). Icariside II-induced mitochondrion and lysosome mediated apoptosis is counterbalanced by an autophagic salvage response in hepatoblastoma. Cancer Lett. 366 (1), 19-31. doi:10.1016/j.canlet.2015.05.032

Goelz, N., Eekels, J. J. M., Pantic, M., Kamber, C. T., Speer, O., Franzoso, F. D., et al. (2021). Platelets express adaptor proteins of the extrinsic apoptosis pathway and can activate caspase-8. PLoS One 16 (1), e0244848. doi:10.1371/journal. pone. 0244848

Groeger, G., Quiney, C., and Cotter, T. G. (2009). Hydrogen peroxide as a cellsurvival signaling molecule. Antioxid. Redox Signaling 11 (11), 2655-2671. doi:10.1089/ars.2009.2728

Guha, M., O'Connell, M. A., Pawlinski, R., Hollis, A., McGovern, P., Yan, S.-F., et al. (2001). Lipopolysaccharide activation of the MEK-ERK1/2 pathway in human monocytic cells mediates tissue factor and tumor necrosis factor $\alpha$

\section{FUNDING}

The present study was supported by the National Natural Science Foundation of China (grant No.82004281) and the Development Plan of Shandong Medical and Health Technology (grant No. 2019WS581).

expression by inducing Elk-1 phosphorylation and Egr-1 expression. Blood 98 (5), 1429-1439. doi:10.1182/blood.v98.5.1429

Guo, F., and Cui, J. (2020). Anti-angiogenesis: opening a new window for immunotherapy. Life Sci. 258, 118163. doi:10.1016/j.lfs.2020.118163

Guo, Y., Wang, C., Jiang, M., Zhu, H., Weng, M., Sun, L., et al. (2020a). Baohuoside I via mTOR apoptotic signaling to inhibit glioma cell growth. Cancer Manag. Res. Vol. 12, 11435-11444. doi:10.2147/CMAR.S265803

Guo, Y., Zhu, H., Weng, M., Chen, B., Wang, C., and Sun, L. (2020b). Baohuoside-1 targeting mTOR inducing apoptsis to inhibit hepatocellular carcinoma proliferation, invasion and migration. Biomed. Pharmacother. 128, 110366. doi:10.1016/j.biopha.2020.110366

Hou, J., Wang, J., Sun, E., Yang, L., Yan, H.-M., Jia, X.-B., et al. (2016). Preparation and evaluation of icariside II-loaded binary mixed micelles using Solutol HS15 and Pluronic F127 as carriers. Drug Deliv. 23 (9), 3248-3256. doi:10.3109/ 10717544.2016 .1167270

Huang, C., Chen, X., Guo, B., Huang, W., Shen, T., Sun, X., et al. (2012). Induction of apoptosis by Icariside II through extrinsic and intrinsic signaling pathways in human breast cancer MCF7 cells. Biosci. Biotechnol. Biochem. 76 (7), 1322-1328. doi:10.1271/bbb.120077

Jin, X., Zhang, Z. H., Sun, E., Qian, Q., Tan, X. B., and Jia, X. B. (2012). Preparation of a nanoscale baohuoside I-phospholipid complex and determination of its absorption: in vivo and in vitro evaluations. Int. J. Nanomedicine 7, 4907-4916. doi:10.2147/IJN.S35965

Jin, X., Zhang, Z.-H., Sun, E., Tan, X.-B., Zhu, F.-X., and Jia, X.-B. (2013). A novel drug-phospholipid complex loaded micelle for baohuoside I enhanced oral absorption:in vivoandin vivoevaluations. Drug Development Ind. Pharm. 39 (9), 1421-1430. doi:10.3109/03639045.2012.719234

Kataoka, T. (2005). The caspase-8 modulator c-FLIP. Crit. Rev. Immunol. 25 (1), 31-58. doi:10.1615/critrevimmunol.v25.i1.30

Kim, B., and Park, B. (2014). Baohuoside I suppresses invasion of cervical and breast cancer cells through the downregulation of CXCR4 chemokine receptor expression. Biochemistry 53 (48), 7562-7569. doi:10.1021/bi5011927

Kudo-Saito, C., Ozaki, Y., Imazeki, H., Hayashi, H., Masuda, J., Ozawa, H., et al. (2021). Targeting oncoimmune drivers of cancer metastasis. Cancers 13 (3), 554. doi:10.3390/cancers 13030554

Lee, K.-S., Lee, H.-J., Ahn, K. S., Kim, S.-H., Nam, D., Kim, D. K., et al. (2009). Cyclooxygenase-2/prostaglandin E2 pathway mediates icariside II induced apoptosis in human PC-3 prostate cancer cells. Cancer Lett. 280 (1), 93-100. doi:10.1016/j.canlet.2009.02.024

Lee, S.-E., Okhlopkova, Z., Lim, C., and Cho, S. (2020). Dracocephalum palmatum Stephan extract induces apoptosis in human prostate cancer cells via the caspase-8-mediated extrinsic pathway. Chin. J. Nat. Medicines 18 (10), 793-800. doi:10.1016/S1875-5364(20)60019-X

Li, S., Zhan, Y., Xie, Y., Wang, Y., and Liu, Y. (2020). The impact of icariside II on human prostate cancer cell proliferation, mobility, and autophagy via PI3KAKT-mTOR signaling pathway. Drug Des. Devel. Ther. Vol.14, 4169-4178. doi:10.2147/DDDT.S268524

Lim, J., and Murthy, A. (2020). Targeting autophagy to treat cancer: challenges and opportunities. Front. Pharmacol. 11, 590344. doi:10.3389/fphar.2020.590344

Ma, H. Y., Liu, X. Z., and Liang, C. M. (2016). Inflammatory microenvironment contributes to epithelial-mesenchymal transition in gastric cancer. World J. Gastronterol. 22 (29), 6619-6628. doi:10.3748/wjg.v22.i29.6619

Majidpoor, J., and Mortezaee, K. (2021). Steps in metastasis: an updated review. Med. Oncol. 38 (1), 3. doi:10.1007/s12032-020-01447-w

Mansilla, S. F., de la Vega, M. B., Calzetta, N. L., Siri, S. O., and Gottifredi, V. (2020). CDK-independent and PCNA-dependent functions of p21 in DNA replication. Genes 11 (6), 593. doi:10.3390/genes11060593

Mercer, T. J., Gubas, A., and Tooze, S. A. (2018). A molecular perspective of mammalian autophagosome biogenesis. J. Biol. Chem. 293 (15), 5386-5395. doi:10.1074/jbc.R117.810366 
Nguyen, K. T. P., Druhan, L. J., Avalos, B. R., Zhai, L., Rauova, L., Nesmelova, I. V., et al. (2020). CXCL12-CXCL4 heterodimerization prevents CXCL12-driven breast cancer cell migration. Cell Signal. 66, 109488. doi:10.1016/j.cellsig.2019. 109488

Ni, F., Tang, H., Wang, C., Zhang, H., Zheng, C., Zhang, N., et al. (2019). Baohuoside I inhibits the proliferation of pancreatic cancer cells via mTOR/ S6K1-caspases/bcl2/bax apoptotic signaling. Cmar Vol. 11, 10609-10621. doi:10.2147/CMAR.S228926

Peng, Y.-G., and Zhang, L. (2018). Baohuoside-I suppresses cell proliferation and migration by up-regulating miR-144 in melanoma. Pharm. Biol. 56 (1), 43-50. doi:10.1080/13880209.2017.1418391

Quan, K., Zhang, X., Fan, K., Liu, P., Yue, Q., Li, B., et al. (2017). Icariside II induces cell cycle arrest and apoptosis in human glioblastoma cells through suppressing Akt activation and potentiating FOXO3a activity. Am. J. Transl Res. 9 (5), 2508-2519.

Ribatti, D., Vacca, A., and Presta, M. (2000). The discovery of angiogenic factors:. Gen. Pharmacol. Vasc. Syst. 35 (5), 227-231. doi:10.1016/s0306-3623(01) 00112-4

Scheau, C., Badarau, I. A., Costache, R., Caruntu, C., Mihai, G. L., Didilescu, A. C., et al. (2019). The role of matrix metalloproteinases in the epithelialmesenchymal transition of hepatocellular carcinoma. Anal. Cell Pathol. 2019, 1. doi:10.1155/2019/9423907

Shah, A. R., and Banerjee, R. (2011). Effect of d- $\alpha$-tocopheryl polyethylene glycol 1000 succinate (TPGS) on surfactant monolayers. Colloids Surf. B: Biointerfaces 85 (2), 116-124. doi:10.1016/j.colsurfb.2011.01.021

Silasi, D. A., Alvero, A. B., Illuzzi, J., Kelly, M., Chen, R., Fu, H. H., et al. (2006). MyD88 predicts chemoresistance to paclitaxel in epithelial ovarian cancer. Yale J. Biol. Med. 79 (3-4), 153-163.

Song, J., Feng, L., Zhong, R., Xia, Z., Zhang, L., Cui, L., et al. (2017). Icariside II inhibits the EMT of NSCLC cells in inflammatory microenvironment via downregulation of Akt/NF-kB signaling pathway. Mol. Carcinog. 56 (1), 36-48. doi:10.1002/mc.22471

Song, J., Shu, L., Zhang, Z., Tan, X., Sun, E., Jin, X., et al. (2012). Reactive oxygen species-mediated mitochondrial pathway is involved in Baohuoside I-induced apoptosis in human non-small cell lung cancer. Chemico-Biol. Interact. 199 (1), 9-17. doi:10.1016/j.cbi.2012.05.005

Sun, Y. S., Thakur, K., Hu, F., Cespedes-Acuña, C. L., Zhang, J. G., and Wei, Z. J. (2020a). Icariside II suppresses cervical cancer cell migration through JNK modulated matrix metalloproteinase-2/9 inhibition in vitro and in vivo. Biomed. Pharmacother. 125, 110013. doi:10.1016/j.biopha.2020.110013

Sun, Y. S., Thakur, K., Hu, F., Zhang, J. G., and Wei, Z. J. (2020b). Icariside II inhibits tumorigenesis via inhibiting AKT/Cyclin E/CDK 2 pathway and activating mitochondria-dependent pathway. Pharmacol. Res. 152, 104616. doi:10.1016/j.phrs.2019.104616

Teleanu, R. I., Chircov, C., Grumezescu, A. M., and Teleanu, D. M. (2019). Tumor angiogenesis and anti-angiogenic strategies for cancer treatment. J. Clin. Med. 9 (1), 84. doi:10.3390/jcm9010084

Thomas, M., Davis, T., Loos, B., Sishi, B., Huisamen, B., Strijdom, H., et al. (2018). Autophagy is essential for the maintenance of amino acids and ATP levels during acute amino acid starvation in MDAMB231 cells. Cell Biochem. Funct. 36 (2), 65-79. doi:10.1002/cbf.3318
Wang, L., Lu, A., Liu, X., Sang, M., Shan, B., Meng, F., et al. (2011). The flavonoid Baohuoside-I inhibits cell growth and downregulates survivin and cyclin D1 expression in esophageal carcinoma via $\beta$-catenin-dependent signaling. Oncol. Rep. 26 (5), 1149-1156. doi:10.3892/or.2011.1400

Wu, J., Guan, M., Wong, P. F., Yu, H., Dong, J., and Xu, J. (2012). Icariside II potentiates paclitaxel-induced apoptosis in human melanoma A375 cells by inhibiting TLR4 signaling pathway. Food Chem. Toxicol. 50 (9), 3019-3024. doi:10.1016/j.fct.2012.06.027

Wu, J., Song, T., Liu, S., Li, X., Li, G., and Xu, J. (2015). Icariside II inhibits cell proliferation and induces cell cycle arrest through the ROS-p38-p53 signaling pathway in A375 human melanoma cells. Mol. Med. Rep. 11 (1), 410-416. doi:10.3892/mmr.2014.2701

Wu, J., Zuo, F., Du, J., Wong, P. F., Qin, H., and Xu, J. (2013). Icariside II induces apoptosis via inhibition of the EGFR pathways in A431 human epidermoid carcinoma cells. Mol. Med. Rep. 8 (2), 597-602. doi:10.3892/mmr.2013.1557

Yan, H. M., Zhang, Z., Jia, X., and Song, J. (2016). D- - -Tocopheryl polyethylene glycol succinate/Solutol HS 15 mixed micelles for the delivery of baohuoside I against non-small-cell lung cancer: optimization and in vitro, in vivo evaluation. Int. J. Nanomed. Vol. 11, 4563-4571. doi:10.2147/IJN.S112204

Yan, L., Xu, F., and Dai, C.-1. (2018). Relationship between epithelial-tomesenchymal transition and the inflammatory microenvironment of hepatocellular carcinoma. J. Exp. Clin. Cancer Res. 37 (1), 203. doi:10.1186/ s13046-018-0887-z

Yang, D. L., Xin, M. M., Wang, J. S., Xu, H. Y., Huo, Q., Tang, Z. R., et al. (2015). Chemokine receptor CXCR4 and its ligand CXCL12 expressions and clinical significance in bladder cancer. Genet. Mol. Res. 14 (4), 17699-17707. doi:10. 4238/2015.December.21.43

Yun, C. W., Jeon, J., Go, G., Lee, J. H., and Lee, S. H. (2020). The dual role of autophagy in cancer development and a therapeutic strategy for cancer by targeting autophagy. Int. J. Mol. Sci. 22 (1), 179. doi:10.3390/ijms22010179

Zhang, J., Li, S., Zhang, S., Wang, Y., Jin, S., Zhao, C., et al. (2020). Effect of icariside II and metformin on penile erectile function, histological structure, mitochondrial autophagy, glucose-lipid metabolism, angiotensin II and sex hormone in type 2 diabetic rats with erectile dysfunction. Sex. Med. 8 (2), 168-177. doi:10.1016/j.esxm.2020.01.006

Zhou, J., Wu, J., Chen, X., Fortenbery, N., Eksioglu, E., Kodumudi, K. N., et al. (2011). Icariin and its derivative, ICT, exert anti-inflammatory, anti-tumor effects, and modulate myeloid derived suppressive cells (MDSCs) functions. Int. Immunopharmacol 11 (7), 890-898. doi:10.1016/j.intimp.2011.01.007

Conflict of Interest: The authors declare that the research was conducted in the absence of any commercial or financial relationships that could be construed as a potential conflict of interest.

Copyright $\odot 2021 \mathrm{Xu}, \mathrm{Wu}, \mathrm{Li}$, Gong, Huo and Cui. This is an open-access article distributed under the terms of the Creative Commons Attribution License (CC BY). The use, distribution or reproduction in other forums is permitted, provided the original author(s) and the copyright owner(s) are credited and that the original publication in this journal is cited, in accordance with accepted academic practice. No use, distribution or reproduction is permitted which does not comply with these terms. 